\title{
KONSELING BEHAVIORAL DAN PENGUATAN POSITIF DALAM MENINGKATKAN PRILAKU SOSIAL PESERTA DIDIK
}

\author{
Oleh: \\ Dewa Kadek Sudyana \\ Universitas Hindu Indonesia Denpasar \\ I Kadek Satria \\ Universitas Hindu Indonesia Denpasar \\ I Ketut Winantra \\ Universitas Hindu Indonesia Denpasar
}

\begin{abstract}
ABSTRAK
Siswa sebagai individu yang melaksanakan proses pembelajaran di sekolah dituntut untuk berperilaku yang baik walaupun terdapat perbedaan dengan individu lainnya.Perilaku sosial Behavioristik menyatakan bahwa tingkah laku manusia dapat diubah atau dimanipulasi, dengan cara mengendalikan tingkah laku manusia, yaitu dengan mengontrol perangsang-perangsang yang ada di lingkungan. Berdasarkan hal tersebut, maka perilaku sosialpun dapat dikembangkan dengan jalan memanipulasinya menggunakan konseling behavioral. Konseling behavioral menekankan pada penguatan perilaku positif. Melalui penerapan bimbingan konseling behavioral akan dapat dibentuk perilaku sosial yang lebih baik.
\end{abstract}

Kata kunci: Konseling behavioral, Penguatan, perilaku sosial

\section{ABSTRACT}

Students as individuals who carry out the learning process at school are required to behave well even though there are differences with other individuals. Behavioristic social behavior states that human behavior can be changed or manipulated, by controlling human behavior, namely by controlling the stimuli that exist in environment. Based on this, then social behavior can be developed by manipulating it using behavioral counseling. Behavioral counseling emphasizes strengthening positive behavior. Through the application of behavioral counseling guidance, better social behavior can be formed

Keywords: behavioral counseling, reinforcement, social behavior

\section{PENDAHULUAN}

Pendidikan dalam arti luas merupakan bantuan atau pertolongan yang diberikan oleh seseorang kepada orang lain untuk mengembangkan dan memfungsionalkan rohani (pikiran, rasa, karsa, cipta dan budi nurani) manusia dan jasmani (pancaindera dan keterampilan-keterampilan) manusia agar meningkat wawasan pengetahuannya. Pendidikan tidak cukup terfokus pada aspek kognitif semata tetapi juga aspek non kognitif. Kedua aspek ini memberi pengaruh yang cukup besar terhadap perkembangan peserta didik. Pendidikan kognitif mengembangkan aspek intelektual, sedangkan aspek non kognitif membantu mengembangkan sikap dan keterampilan (Trisdyani \& Suadnyana, 2019).
Sebagaimana diketahui bahwa perilaku manusia dipengaruhi oleh dua faktor besar yaitu faktor internal dan faktor eksternal. Faktor eksternal meliputi masyarakat, keluarga dan sekolah. Masyarakat selain berperan sebagai pemberi masukan dalam mengembangkan pendidikan, juga membantu menyediakan sarana dan prasarana belajar. Sedangkan keluarga berperan sebagai peletak pengetahuan dan pengalaman dasar bagi anakanak. Keluarga merupakan sumber pendidikan utama, karena segala pengetahuan dan kecerdasan intelektual manusia diperoleh pertama-tama dari orang tua dan anggota keluarganya sendiri (Trisdyani, 2019).

$$
\text { Selain keluarga sebagai tempat }
$$

pendidikan anak, sekolah berperan 
melanjutkan pendidikan keluarga dengan memberi pengetahuan dan keterampilan melalui pendidikan akademis dan non akademis. Demikianlah pendidikan itu dilakukan dalam tiga tempat untuk saling melengkapi. Dalam Undang-Undang sistem pendidikan Nasional No: 20 / 2003 Bab I Ketentuan Umumt ayat 2 tentang sitem Pendidikan tertera bahwa, "semua proses pendidikan itu bertujuan untuk mewujudkan suasana belajar dan proses pembelajaran agar peserta didik secara aktif mengembangkan potensi dirinya untuk memiliki kekuatan spiritual keagamaan, pengendalian diri, kepribadian, kecerdasan, akhlak mulia, serta keterampilan yang diperlukan dirinya, masyarakat, bangsa dan negara".

Akan Tetapi kondisi di lapangan mengindikasikan bahwa sekolah lebih mengutamakan nilai hasil belajar/akademik dari pada pengembangan kepribadian. Persyaratan untuk memasuki sekolah pada jenjang pendidikan tertentu menggunakan nilai Ujian bahkan sampai pada tahap seleksi TPA (Tes Potensi Akademik), dan persyaratan akademis lainnya. Jarang kita mendengar ada sekolah yang menggunakan kepribadian sebagai persyaratan utama diterima sebagai siswa baru pada sekolah tertentu. Akibatnya banyak sekolah yang hanya menekankan pada bagaimana caranya agar nilai akademis anak dapat ditingkatkan. Dampak lanjutannya adalah anak banyak diberikan les-les atau bimbingan belajar, baik yang dilaksanakan di sekolah maupun di luar sekolah, diselenggarakannya lomba-lomba peningkatan prestasi akademik seperti olimpiade matematika, fisika, bologi, dan berbagai jenis lomba akademik lainnya.

Akibat dari adanya ketidakseimbangan kedua aspek pendidikan tersebut, anak terkesan menjadi anak pintar tetapi angkuh dan meninggalkan aspek emosional. Goleman (2003: 48) menyatakan bahwa "keberhasilan seseorang dalam hidup, dalam hal ini keberhasilan berperilaku sosial yang positif bukan hanya ditentukan oleh kecerdasan intelektual semata akan tetapi banyak dipengaruhi oleh kecerdasan emosional. Banyak bukti yang memperlihatkan bahwa orang yang secara emosional cakap mengelola perasaan dengan baik, dan yang mampu membaca serta menghadapi perasaan orang lain dengan efektif memiliki keuntungan dalam bidang hidup. Sebagaimana dikatakan oleh Sunaryo Kartadinata, dkk (2000 : 06) bahwa, "kebermutuan SDM tidak hanya terletak pada kecerdasan intelektual, tetapi juga kecerdasan sosial dan emosional". Keberhasilan atau prestasi yang dicapai manusia masyarakat global tidak semata-mata ditentukan oleh kecerdasan intelektual tapi juga oleh ketekunan, komitmen, motivasi, kesungguhan, disiplin dan etos kerja, kemampuan berempati, berinterelasi dan berinterelasi.

Jadi, perilaku sosial memegang peranan penting dalam kehidupan. Hal ini merupakan salah satu aspek non kognitif yang seringkali dilupakan peranannya. Indikasi perilaku sosial yang baik adalah seperti sopan santun, kemampuan berempati, suka bekerjasama, membantu orang lain, tidak memaksakan kehendak kepada orang lain akan memperoleh penyesuaian yang baik di masyarakat dan bisa diterima masyarakat serta terciptanya keharmonisan hubungan antar sesama. Sebaliknya, orang yang cerdas secara intelektual akan tetapi tidak tahu bagaimana bergaul, egois, ingin menang sendiri, tidak menghargai orang lain, tidak akan diterima baik oleh masyarakat dalam pergaulannya.

Sekolah sebagai salah satu lingkungan pendidikan yang terdiri dari berbagai macam individu dengan segala perbedaan masingmasing sangat memungkinkan anak untuk dapat megembangkan perilaku sosialnya karena di sekolah mereka berinteraksi dengan orang yang berbeda dan belajar menerima perbedaan tersebut. banyak siswa yang menunjukkan perilaku sosial yang rendah, baik di kelas maupun di luar kelas. Indikator ini terlihat antara lain, perilaku siswa yang sering membuat keributan di kelas walaupun ada guru yang sedang mengajar, mengejek teman yang sering berakhir dengan perkelahian/ permusuhan, kurangnya sikap empati pada teman, berperilaku kurang sopan pada guru yang ditunjukan dengan kurangnya sopan santun ketika berbicara dengan guru.

Agar gejala-gejala seperti ini tidak terus berkembang, maka perlu dilakukan usaha-usaha yang bersifat preventif maupun kuratif. Untuk mengubah perilaku sosial yang negatif kearah perilaku positif, salah satu cara yang digunakan adalah dengan pendekatan konseling behavioral. Corey yang diterjemahkan oleh Koeswara, (1988: 197) menyatakan behaviorisme adalah suatu pandangan ilmiah tentang tingkah laku 
manusia. Dalil dasarnya adalah bahwa perilaku yang di bentuk berdasarkan hasil dari segenap pengalamannya berupa interaksi individu dengan lingkungan sekitarnya.

Dalam konsep behavioral, perilaku manusia merupakan hasil belajar, sehingga dapat diubah dengan memanipulasi dan mengkreasi kondisi-kondisi belajar. Pada dasarnya proses konseling merupakan suatu penataan proses atau pengalaman belajar untuk membantu individu mengubah perilakunya agar dapat memecahkan masalahnya. Menurut Krumboltz dan Thoresen dalam Surya, (1988: 186) "konseling behavioral adalah sutau proses membantu orang untuk belajar memecahkan masalah interpersonal, emosional, dan keputusan tertentu". Penekanan istilah belajar dalam pengertian ini adalah atas pertimbangan bahwa konselor membantu klien belajar atau mengubah perilaku. Konselor berperan membantu dalam proses belajar dengan menciptakan kondisi yang sedemikian rupa sehingga klien dapat mengubah perilakunya serta memecahkan masalahnya.

Ada beberapa model yang dapat digunakan untuk mengubah perilaku dengan pendekatan behavioristik. Model-model yang dimaksud adalah model Disensitisasi Sistematik, Implosive, Aversi, dan Pengkondisian Operant. Salah satu model yang digunakan dalam penelitian ini adalah model pengkondisian operan, dengan metode penguatan positif. Penguatan positif merupakan pembentukan suatu pola tingkah laku dengan memberikan ganjaran atau penguatan segera setelah tingkah laku yang diharapkan muncul. Cara ini adalah cara yang cukup ampuh dalam mengubah tingkah laku (Suadnyana, 2020).

Menurut Skinner dalam E. Koeswara, (1988: 222), penguatan positif jauh lebih efektif dalam mengendalikan tingkah laku karena hasil-hasilnya lebih bisa diramalkan serta kemungkinan timbulnya tingkah laku yang tidak diinginkan akan lebih kecil.

\section{PEMBAHASAN}

\subsection{Konseling Model Behavioral}

Behaviorisme adalah suatu pandangan ilmiah tentang tingkah laku manusia. Dalil dasarnya adalah bahwa tingkah laku itu tertib dan bahwa eksperimen yang dikendalikan dengan cermat akan menyingkapkan hukum hukum yang mengendalikan tingkah laku.
Behaviorisme menitik beratkan pada perilaku individu. Menurutnya, perilaku individu ada karena adanya stimulus (rangsangan eksternal). Reaksinya berupa gerak dan perubahan jasmani yang bisa diamati secara objektif, serta bisa dipelajari dari luar. Manusia dikatakan sebagai makhluk kebiasaan belaka sehingga dia bisa dijadikan sedemikian rupa, dengan jalan memberi perangsangperangsang yang tepat dan momen yang baik, sehingga ada proses belajar dan berlatih.

Menurut Watson dalam Rosjidan (1988: 230) yang merupakan pelopor behaviorisme radikal menyatakan bahwa reaksi-reaksi dan refleks-refleks bisa dikordinir dan direkondisioner sehingga semua kebiasaan yang keliru bisa di-rekondisioner lagi. Sesuai dengan pernyataan di atas, maka perilaku sosialpun bisa dirubah atau dikembangkan dari perilaku sosial rendah menjadi perilaku sosial yang lebih tinggi. Menurut Santrock dan Yussen dalam Semiawan, (1999: 264) bahwa perilaku tersebut akan menjadi kebiasaan jika diulang-ulang (semakin sering) perilakunya dimunculkan anak.

Dalam pandangan behavioral, kepribadian manusia itu pada hakikatnya adalah perilaku. Perilaku di bentuk berdasarkan hasil dari segenap pengalamannya berupa interaksi individu dengan lingkungan sekitarnya. Tidak ada manusia yang sama, karena kenyataannya manusia memiliki pengalaman yang berbeda dalam kehidupannya. Kepribadian seseorang merupakan cerminan dari pengalaman, yaitu situasi atau setimulus yang diterimanya.

Corey dalam Koeswara, (1988: 200) menyatakan "bahwa pada dasarnya terapi tingkah laku diarahkan pada : a). Penetapan tujuan treatment secara rinci, yaitu treatment dispesifikasi dan diuraiakan dalam sub-sub tujuan yang lebih khusus. Tujuan-tujuan tersebut dimaksudkan untuk memperoleh tingkah laku yang maladaptif serta memperkuat serta memepertahankan tingkah laku yang diinginkan, b). Setelah tujuan terinci selanjutnya adalah menetapkan metodemetode yang paling sesuai untuk mencapai tujuan-tujuan itu, (c) hasil-hasil terapi selanjutnya bisa dievaluasi. Evaluasi dapat dilakukan untuk mengetahui keefektifan teknik-teknik yang digunakan berdasarkan pada sejauh mana tujuan telah tercapai. Perlu diingat pula adalah bahwa proses tersebut tetap melibatkan pemberian 
ganjaran/penguatan kepada individu, yaitu reiforcement ketika perilaku yang diinginkan muncul atau punishment ketika perilaku yang tidak diinginkan muncul”.

Tujuan umum terapi behavioral adalah menciptakan kondisi baru untuk belajar. Asumsinya adalah pengalaman belajar yang demikian itu akan dapat memperbaiki tingkah laku bermasalah. Tujuan konseling harus dipertajam sampai kepada titik yang jelas, konkrit, dipahami, dan disetujui oleh klien dan konselor. Dasar alasannya adalah bahwa segenap tingkah laku dipelajari (learned), termasuk tingkah laku yang maladaptif. Jika tingkah laku neurotik learned, maka bisa unlerned (dihapus dalam ingatan), dan tingkah laku yang lebih efektif bisa diperoleh.

Menurut Krumboltz dan Thoresen dalam Mohammad Surya, (1988 : 186) konseling behavioral adalah suatu proses membantu orang untuk belajar memecahkan masalah interpersonal, emosional, dan keputusan tertentu. Penekanan istilah belajar dalam pengertian ini adalah atas pertimbangan bahwa konselor membantu klien belajar atau mengubah perilaku. Konselor berperan membantu dalam proses belajar dengan menciptakan kondisi yang sedemikian rupa sehingga klien dapat mengubah perilakunya serta memecahkan masalahnya. Berperilaku sosial juga merupakan proses belajar sehingga cocok untuk diberikan konseling behavioral.

Cormier dan Cormier dalam Rosjidan, (1988: 238) mengemukakan urutan-urutan pemilihan dan penentuan tujuan konseling, (a) konselor menerangkan maksud dan tujuan, (b) klien merinci perubahan positif yang diinginkan sebagai hasil konseling, (c) klien dan konselor menentukan apakah tujuantujuan yang dirumuskan adalah perubahanperubahan yang "dimiliki" oleh klien, (d) bersama-sama mereka mengekplorasi apakah tujuan-tujuan itu realitas, (e) mereka membahas keuntungan-keuntungan tujuan yang mungkin, (f) mereka membahas kerugian-kerugian tujuan yang mungkin, $(\mathrm{g})$ atas dasar informasi yang diproleh mengenai tujuan-tujuan yang dirumuskan klien, konselor dan klien membuat salah keputusan, yaitu melanjutkan konseling, meninjau kembali tujuan klien, atau mencari referral.

\subsection{Teknik Behavioral}

Gerald Corey dalam E. Koeswara, (1988: 211) menyatakan, dalam terapi tingkah laku, teknik-teknik spesifik dapat digunakan secara sistematis, dan hasil-hasilnya bisa dievaluasi. Teknik-teknik ini bisa diguanakan jika saatnya tepat untuk menggunakannya, dan banyak diantaranya yang bisa dimasukan ke dalam praktek psikoterapi yang berlandaskan model-model lain. Teknik-teknik spesifik yang akan diuraikan di bawah ini bisa ditetapkan pada terapi dan konseling individu maupun kelompok. Teknik-teknik utama terapi tingkah laku diantaranya:

a. Disentisisasi sistematik, adalah salah satu teknik yang paling luas digunakan dalam terapi tingkah laku. Disentisisasi sistematik digunakan untuk menghapus tingkah laku yang diperkuat secara negatif, dan ia menyertakan pemunculan tingkah laku atau respon yang berlawanan dengan tingkah laku yang hendak dihapuskan itu, disentisisasi diarahkan kepada mengajar klien untuk menampilkan suatu respon yang tidak konsisten dengan kecemasan.

b. Teori impolsive dan pembanjiran. Teknik pembanjiran berlandaskan paradigma mengenai penghapusan eksperimental. Teknik ini terkurang atas pemunculan stimulus berkondisi secara berulang-ulang tanpa pemberian penguatan. Teapis memunculkan stimulus-stimulus penghasil kecemasan, klien membayangkan situasi, dan terapis berusaha memepertahankan kecamasan klien. Stampfl yang diterjemahkan oleh Koeswara (1988: 215) mencatat beberapa contoh bagaimana terapi impolsive berlangsung. Ia melukiskan seseorang klien yang mengalami kecendrungankecendrungan obsesif kepada kebersihan, klien akan mencuci tangannya lebih dari seratus kali sehari dan memiliki ketakutan yang berlainan terhadap kuman.

c. Latihan asertif. Pendekatan behavioral yang dengan cepat mencapai popularitas adalah latihan asertif, yang bisa diterapkan terutama pada situasi-situasi interpersonal dimana individu mengalami kesulitan untuk menerima kenyataan bahwa menyatakan atau menegaskan diri adalah tindakan yang layak atau benar. Gunarsa (2004 : 215) menyatakan bahwa, latihan asertif adalah salah satu dari sekian banyak topik yang tergolong populer dalam terapi perilaku. Latihan asertif akan membantu bagi orang-orang 
yang: (1) tidak mampu mengungkapkan kemarahan atau perasaan tersinggung, (2) menunjukan kesopanan yang berlebihan atau selalu mendorong orang lain untuk mendahuluinya, (3) memiliki kesulitan untuk menyatakan tidak "tidak", (4) mengalami kesulitan untuk mengungkapkan afeksi dan respon-respon positif lainnya, (5) merasa tidak punya hak untuk memiliki perasaan-perasaan dan pikiran-pikiran sendiri. Pendekatan ini berlangsung menggunakan metodemetode permainan peran.

d. Terapi aversi. Teknik-teknik pengondisian aversi, yang telah digunakan secara luas untuk meredakan gangguan-gangguan behavioral yang spesifik, melibatkan pengengasosian tingkah laku simtomatik dengan satu stimulus yang menyakitkan sampai tingkah laku yang tidak diinginkan terhambat kemunculannya. Stimulusstimulus aversi aversi biasanya berupa hukuman dengan kejutan listrik atau pemberian ramuan yang membuat mual. Kendali aversi bisa melibatkan penarikan pemerkuat positif atau penggunaan berbagai bentuk hukuman. Skinner adalah salah satu tokoh yang terangterangan menentang penggunaan hukuman sebagai cara untuk mengendalikan hubungan-hubungan manusia ataupun mencapai maksudmaksud lembaga-lembaga masyarakat. Menurut Skinner, penguatan positif jauh lebih efektif dalam mengendalikan tingkah laku karena hasil-hasilnya lebih bisa diramalkan serta kemungkinan timbulnya tingkah laku yang tidak diinginkan akan lebih kecil. Skinner berpendapat bahwa hukuman adalah sesuatu yang buruk yang meskipun bisa menekan tingkah laku yang diinginkan, tidak melemahkan kecendrungan untuk merespon bahkan kalaupun ia untuk sementara menekan tingkah laku tertentu. Akibat-akibat yang tidak diinginkan, menurut Skinner, berkaitan dengan penggunaan pengendalian aversif maupun penggunaan hukuman (Suadnyana, 2020).

e. Pengondisian operant salah satu aliran utama lainnya dari pendekatan terapi yang berlandaskan teori belajar, melibatkan pemberian ganjaran kepada individu atas pemunculan tingkah lakunya (yang diharapkan) pada saat tingkah laku itu muncul. Pengkondisian operant ini dikenal juga dengan sebutan pengkondisian instrumental karena memperlihatkan bahwa tingkah laku instrumental bisa dimunculkan oleh organis yang aktif sebelum penguatan itu diberikan untuk tingkah laku tersebut. Skinner, yang dianggap sebagai pencetus gagasan pengkondisian operant, telah mengembangkan prinsip-prinsip penguatan yang dipergunakan pada upaya memperoleh pola-pola tingkah laku tertentu yang dipelajari. Dalam pengkondisian operant, pemberian penguatan positif bisa memperkuat tingkah laku, sedangkan pemberian penguatan negative bisa memperlemah tingkah laku. Tingkah laku berkondisi muncul dilingkungan instrumental bagi perolehan ganjaran.

Beberapa metode pengkondisian operant adalah: penguatan positif, pembentukan respon, penguatan intermitan, penghapusan pencontohan dan token economy. Dari beberapa jenis metode dalam konseling behavioral, peneliti hanya menggunakan satu metode saja yaitu penguatan positif. Skinner mengungkapkan bahwa penguatan positif jauh lebih efektif dalam mengendalikan tingkah laku karena hasil-hasilnya lebih bisa diramalkan serta kemungkinan timbulnya tingkah laku yang tidak diinginkan akan lebih kecil.

Penguatan positif, pembentukan suatu pola tingkah laku dengan memberikan ganjaran atau penguatan segera setelah tingkah laku yang diharapkan muncul, cara ini adalah cara yang cukup ampuh dalam mengubah tingkah laku. Pemerkuat-pemerkuat, baik primer maupun sekunder, diberikan untuk rentang tingkah laku yang luas.

\subsection{Perilaku Sosial}

Menurut Thantawy dalam Mastiningsih, (2005 : 28) yang dimaksud dengan perilaku sosial adalah keanekaragaman tingkah laku atau respon yang dilakukan dalam interaksi antar individu dalam suatu lingkungan sosial tertentu. Sebagaimana diungkap oleh Achir dalam Mastiningsih, (2005 : 28), indikator perilaku sosial adalah sebagai berikut: (1) ikut merasakan kebahagiaan dan penderitaan orang lain; (2) mendengarkan pendapat orang lain; (3) mengajukan pendapat dalam kelompok; (4) 
mengajukan pujian atau kesan baik pada teman; (5) menyampaikan kritik atau kesan jelek pada teman secara bijaksana; (6) menerima pujian secara bijaksana; (7) menerima kritik secara terbuka. Seperti kita tahu bahwa manusia tidak dapat hidup sendiri tanpa bantuan manusia lainnya. Untuk dapat hidup rukun dan harmonis, maka manusia diatur oleh norma-norma yang berlaku. Norma-norma tersebut membatasi perilaku manusia. Apabila norma-norma tersebut dilanggar maka akan ada sanksi yang akan mengikutinya. Sanksi tersebut ada yang ringan dan ada pula yang berat, tergantung dari jenis pelanggaran yang dilakukan. Sebagai anggota masyarakat, tentunya kita menginginkan agar perilaku sosial yang dilakukan adalah tidak bertentangan dengan masyarakat lain.

Perilaku sosial yang diharapkan tentu saja perilaku yang prososial. Pengertian perilaku prososial menurut Staub, Baron \& Byren dalam Dayakisni \& Hudaniah, (2003 : 177) dapat dimengerti sebagai perilaku yang menguntungkan penerima, tetapi tidak memiliki keuntungan yang jelas bagi pelakunya. Disisi lain William dalam Dayakisni \& Hudaniah, (2003 : 177) membatasi perilaku prososial secara lebih rinci sebagai perilaku yang memiliki intensi untuk mengubah keadaan fisik atau psikologis penerima bantuan dari kurang baik menjadi lebih baik, dalam arti secara material maupun psikologis. Lebih jauh lagi Eiseberg \& Mussen dalam Dayaksini \& Hudaniah, (2003 : 177) menyatakan bahwa, pengertian perilaku prososial mencakup tindakan-tindakan : Sahring (membagi), cooperative (kerjasama), donating (menyumbang), helping (menolong), bonesty (kejujuran), generosity (kedermawanan), serta mempertimbangkan hak dan kesejahteraan orang lain. ada tiga indikator yang menjadi tindakan prososial, yaitu :

a. Tindakan itu berakhir pada dirinya dan tidak menuntut keuntungan pada pihak pelaku.

b. Tindakan itu dilahirkan secara sukarela.

c. Tindakan itu menghasilkan kebaikan.

Perilaku manusia sebagian terbesar adalah perilaku yang dibentuk atau perilaku yang dipelajari. Bimo Walgito, (2001 : 18). Perilaku yang ada pada individu tidak timbul dengan sendirinya, tetapi sebagai akibat dari stimulus yang diterima oleh organisme yang bersangkutan baik stimulus internal maupun stimulus eksternal. Seseorang berperilaku karena ia didorong oleh suatu motif tertentu yang harus dipenuhi. Motif inilah yang menyebabkan manusia aktif.

\section{PENUTUP}

Perilaku sosial merupakan salah satu perwujudan dari hakekat manusia, yaitu sebagai mahkluk sosial. Sebagai mahkluk sosial, manusia berinteraksi dengan manusia lainnya dalam rangka memenuhi kebutuhannya. Dalam interaksi tersebut, individu berbaur dengan individu lainnya dengan membawa segenap perbedaan yang dimilikinya. Dalam pergaulan tersebut, ada yang bisa menyesuaikan diri dengan baik sehingga perilakunya menjadi baik, tetapi tidak jarang adapula individu yang tidak bisa menyesuaikan diri sehingga perilakunya di masyarakat juga menjadi tidak baik. Perilaku yang tidak baik tersebut akan berkembang menjadi perilaku menyimpang.

Siswa sebagai individu yang melaksanakan proses pembelajaran di sekolah dituntut untuk berperilaku yang baik walaupun terdapat perbedaan dengan individu lainnya. Perilaku itu dibatasi oleh aturan-aturan yang telah ditetapkan sekolah. Pada kenyataannya, banyak siswa yang menunjukkan perilaku sosial rendah, walaupun setiap hari telah dilakukan pembinaan, baik oleh guru ataupun guru pembimbing. Perilaku sosial yang rendah tersebut ditunjukkan dengan seringnya siswa membuat keributan, baik di kelas maupun di luar kelas, seperti sering berkelahi, menyakiti perasaan teman, saling ejek, memaksakan kehendak pada orang lain, suka mengkritik teman dan tidak suka dikritik, dan sebagainya. Perilaku sosial tersebut sangat berperan dalam keseluruhan keberhasilan siswa dalam belajarnya, bukan hanya belajar dalam pengembangan aspek kognitif saja tetapi juga pengembangan aspek afektif.

Perilaku menyimpang tersebut sangat berbahaya bagi anak karena dapat merugikan tidak hanya dirinya sendiri tetapi juga orang lain (keluarga, sekolah, masyarakat). Pada dasarnya perilaku yang tidak baik/perilaku menyimpang dapat berubah menjadi perilaku yang baik. Hal ini disebabkan karena perilaku tersebut dipelajari sehingga perilaku juga bisa diubah. Untuk membina perilaku sosial banyak cara telah dilakukan, diantaranya dengan menetapkan tata tertib yang harus 
ditaati oleh siswa, kegiatan ekstrakurikuler maupun kokurikuler di sekolah, pembentukan kelompok belajar, perkumpulan pemuda pemudi, dan sebagainya. Semua cara di atas telah banyak dilakukan. Hal ini sejalan dengan pemikiran behavioral yang menekankan pada cara pengubahan perilaku. Behavioristik menyatakan bahwa tingkah laku manusia dapat diubah atau dimanipulasi, dengan cara mengendalikan tingkah laku manusia, yaitu dengan mengontrol perangsang-perangsang yang ada di lingkungan. Berdasarkan hal tersebut, maka perilaku sosialpun dapat dikembangkan dengan jalan memanipulasinya menggunakan konseling behavioral. Konseling behavioral menekankan pada penguatan perilaku positif. Melalui penerapan bimbingan konseling behavioral akan dapat dibentuk perilaku sosial yang lebih baik.

\section{DAFTAR PUSTAKA}

Corey, Gerald. (E. Koeswara. Penerjemah) 1988. Teori Praktek dan konseling dan Psikotrapi. Bandung : PT. Refika Aditama

Dayaksini dan Hudaniah. 2003. Psikologi Sosial. Malang : UMM Press

Eka Suadnyana, I. B. (2020). IMPLEMENTASI NILAI ETIKA HINDU PADA GEGURITAN NI SUMALA. Bawi Ayah: Jurnal Pendidikan Agama Dan Budaya Hindu, 11(1), 100-116. https://doi.org/10.33363/ba.v11i1.445

Juntika Nurhisan, Achmad. 2005. Strategi Layanan Bimbingan dan Konseling. Bandung: PT. Refika Aditama

Latipun. 2002. Psikologi Konseling. Malang : UMM Press

Mappiare, Andi. 2004. Pengantar Konseling Dan Psikoterapi. Jakarta : PT.Raja Grafindo Persada

Prayitno dan Erman Amti.1999. Dasar-dasar Bimbingan dan Konseling. Jakarta : Rineka Cipta.

Rosjidan, 1988. Pengantar Teori-teori Konseling. Jakarta : Departemen Pendidikan dan Kebudayaan.

Sarlito Wirawan Sarwono, 2002. Psikologi Sosial (Individu dan Teori-teori Psikologi Sosial). Jakarta : Balai Pustaka.

Semiawan, Cony R. 1999. Perkembangan dan Belajar Peserta Didik. Departemen Pendidikan dan Kebudayaan.

Thantawy. 1993. Kamus Bimbingan dan Konseling. Jakarta : Economics Student's Group.

Walgito, Bimo. 1995. Bimbingan dan Penyuluhan Di Sekolah. Yogyakarta : Andi Offset.

Walgito, Bimo. 2001. Psikologi Sosial (Suatu Pengantar). Yogyakarta : Andi.

Yusuf Syamsu dan Nurhisan Juntika. 2005. Landasan Bimbingan Konseling. Bandung : Remaja Rosdakarya. 